\title{
Steroid Prohormones: Effects on Body Composition in Athletes
}

\author{
Sergej M. Ostojic, Julio Calleja-Gonzalez and Marko Stojanovic \\ Center for Health, Exercise and Sport Sciences, Belgrade \\ Serbia
}

\section{Introduction}

Androgenic-anabolic steroid hormones (AAS) are synthetic derivatives of the male hormone testosterone and for many years have been popular among athletes both for performance enhancement, due to physiological and psychological effects, and for aesthetic reasons (Evans 2004; Hartgens \& Kuipers 2004). The anabolic action of AAS is particularly interesting since its affects protein metabolism by stimulation of protein synthesis and inhibition of protein breakdown, which could induce muscle growth and enhance adaptation to resistance training (Yesalis \& Bahrke 1995; Brown et al. 2006). Since the AAS use in sport is banned, different nutritional strategies have been developed in the past decades to circumvent this problem and administer other exogenous testosterone analogues (King et al. 1999).

In the past 2o years, different steroid prohormones or prosteroids (e.g. androstenedion, dehydroepiandrosterone, androstenediol, 19-nor androstenediol, 19-nor androstenedione, 1testosterone) have been developed and aggressively marketed in athletic environment as legal nutritional supplements that are expected to convert to active anabolic steroid hormones in the body and enhance exercise performance (Brown et al. 1999; Brown et al. 2000; Earnest et al. 2000; Leder et al. 2000; Brown et al. 2001; Kanayama et al. 2001). The efficacy and safety of these prohormones are not well established but are highly promoted to have the same androgenic effects on building muscle mass and strength as AAS (Baulieu et al. 2000; Brown et al. 2006). A typical steroid prohormone is intended to be a precursor to both testosterone and estrogens, through different biochemical pathways (Figure 1), typically resulting in the action of dehydrogenases in skeletal muscle, adipose tissue, skin, prostate and adrenal gland (Griffin 2004).

Dehydroepiandrosterone (3 $\beta$-hydrohy-5-androsten-17-one; DHEA) seems to be the master steroid prohormone due its precursor function and its conversion to other hormones (Brown et al. 2006). Although the mechanism of action of DHEA or other prosteroids is not completely understood, it could be hypothesized that DHEA could increase testosterone production (at least as an acute response) if supplemented in diet, and due to its anabolic action may affects nitrogen balance and protein synthesis (Morales et al. 1998).

Testosterone is synthesized through either the $\Delta-4$ or $\Delta-5$ pathway (Broeder 2003) with the effects of newly synthesized testosterone in humans occur by way of 2 main mechanisms: by activation of the androgen receptor (directly or as $5 \alpha$-dihydrotestosterone), and by conversion to estradiol and activation of estrogen receptors (Wilson 1988). Free testosterone 


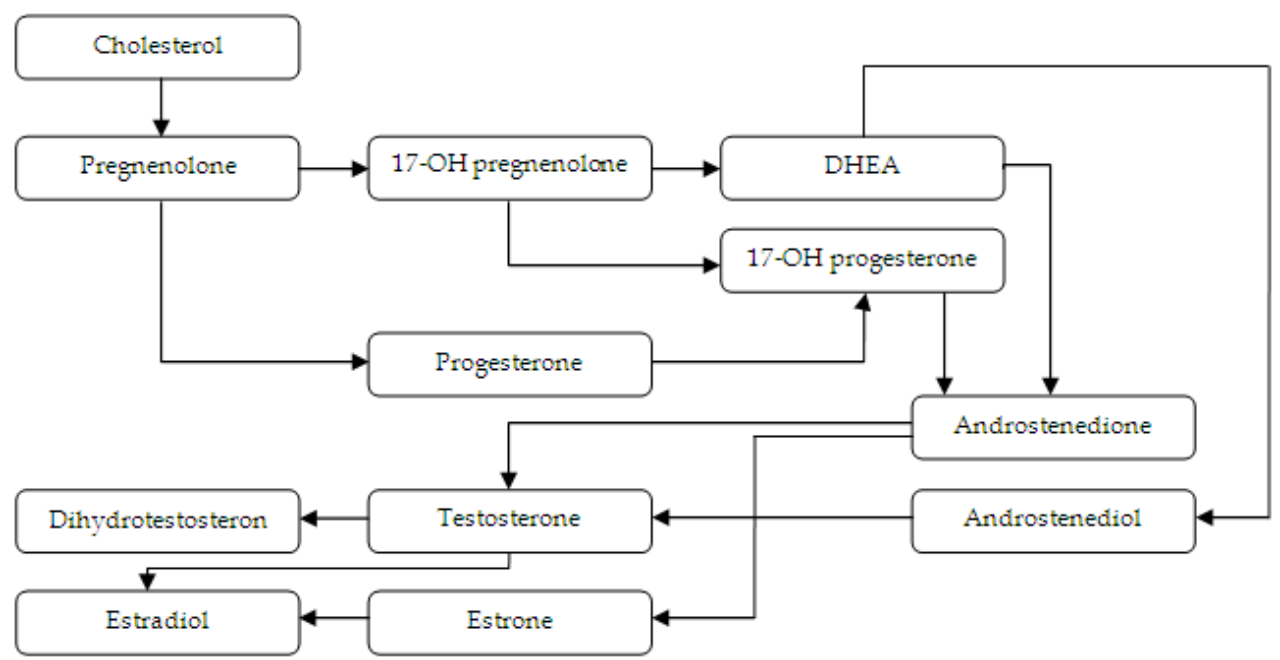

Fig. 1. Androgens biosynthesis from cholesterol to testosterone/dihydrotestosterone and estrogens (estrone and estradiol) via prohormone precursors (e.g. DHEA, androstenedione, androstenediol). Abb. DHEA - dehydroepiandrosterone.

is transported into the cytoplasm of target tissue cells, where it can bind to the androgen receptor, or can be reduced to $5 \alpha$-dihydrotestosterone (DHT) by the cytoplasmic enzyme 5alpha reductase (Hartgens \& Kuipers 2004). DHT binds to the same androgen receptor even more strongly than testosterone, so that its androgenic potency is about 5 times that of testosterone (Breiner et al. 1986). The testosterone-receptor or DHT-receptor complex undergoes a structural change that allows it to move into the cell nucleus and bind directly to specific nucleotide sequences of the chromosomal desoxiribonucleic acid. The areas of binding are called hormone response elements, and influence transcriptional activity of certain genes, producing the anabolic effects (Saartok et al. 1984). Theoretically, the fewer interconversion steps a prohormone must complete in the syntheisis pathway to testosterone, the greater potential for enhancing active hormone production (Broeder 2003); for example, androstenedione converts to testosterone more rapidly than DHEA.

Existing data suggest that acute oral ingestion of DHEA, androstenediol or androstenedione modestly and transiently increase serum testosterone concentration; however, this is accompanied by greater increase in other steroids as well (i.e. estrogens, luteinizing hormone) (Ziegenfuss et al. 2002). Yet, it is questionable if this acute elevation in testosterone concentration induced by prosteroids necessarily result in enhanced transcriptional activity (Broeder 2003). Furthermore, research has shown that prosteroids may have significant biological activity by itself (Ostojic et al. 2009, Ostojic et al. 2010), affecting resting metabolic rate through futile cycling (Tagliaferro et al. 1986), increasing the flux of fatty acids through $\beta$-oxidation (Mohan et al. 1988), and alter the level of serotonin and dopamine (Cleary 1991; Ebeling et al. 1994; Kroboth 1999). Yet, the mechanism of action of prosteroids may differ between compounds because of variations in the steroid molecules (Hartgens \& Kuipers 2004). These differences could be responsible for differences in the specificity of binding to receptor proteins or to interactions with various steroidmetabolizing enzymes (Wilson 1988; Creutzberg \& Schols 1998) with future research needed to clarify the explaining physiological effects due to prosteroids use in humans. 


\section{History of steroid prohormones use in sport and exercise}

Although the first documented reports of misuse of AAS by athletes stem from the 1950s (Yesalis 1999), the use of prosteroids in the athletic environment is rather new. Prosteroids were indirectly introduced with US Anabolic Steroid Control Act of 1990 (21 USCS Section 802), which defined anabolic steroids as "...any drug or hormonal substance that promotes muscle growth in a manner physiologically similar to testosterone...", while steroid prohormones were not classified as anabolic steroids and could be purchased legally as dietary supplements (Broeder 2003; Brown et al. 2006). This document didn't appear to make a significant decrease in the use of anabolic steroids (Brainum 2008), but concern about the side effects linked to steroid use did lead to the development of another popular anabolic offering: prohormone nutritional supplements (Brown et al. 2003).

In December of 1996, androstenedione became available for over-the-counter sales in United States (Ziegenfuss et al. 2002), with subsequent availability of several other prohormones (e.g. androstenediol, DHEA, norandrostenedione). The non-critical promotion era of prosteroids in sport began with the disclosure of androstenedione use by Mark McGwire in 1998, who at the time was elite baseball player, which stimulated extensive media attention and dramatically increased the sales of prohormones among recreative and professional athletes (Brown et al. 2003, Brown et al. 2006).

In the past decades, prohormones have been highly marketed in the field of sport as lean body mass builders, fat reduction agents, and anticatabolic compounds. Recently, concerns over the safety of the prohormones use induced changes in US Anabolic Steroid Control Act in 2004 (21 USCS Section 802, amended), redefining anabolic steroids and classify prohormones as controlled substances. While the 2004 amendment specifically mentioned most of the current prohormones by name, that didn't stop some companies from marketing at least one anabolic steroid that the lawmakers had overlooked (Brainum 2008).

At the moment, it seems that legal status of prohormones is different throughout the world. In USA, Canada or Australia prosteroids are recognized as controlled substances and it is illegal to own or sell the product without prescription. On the other hand, no prescription is required for prosteroids purchase in several European countries, Russia or Japan, with products recognized as over-the-counter dietary supplements.

\section{Epidemiology of steroids use among athletes: scope of the problem}

Anabolic steroid usage has been recognized as a serious health and ethical problem among athletes for several decades (Foster \& Housner 2004). Numerous examples of steroid usage rules violations have been highly publicized and have lead to the suspension and stripping of medals from international athletes, as well as many professional athletes (International Olympic Committee 1997; Wroble et al. 2002). Elite athletes are not the only population of individuals that use steroids. Recreational athletes also use steroids to enhance performance and to improve personal appearance (Wroble et al. 2002). Furthermore, evidence indicates that steroid usage often starts during high school (Yesalis et al, 1989; Kerr and Congeni 2007). Use of anabolic steroids is widespread in the athletic environment, particularly in power events and disciplines (e.g. football, track and field, body building, power lifting) (Foster \& Housner 2004).

It seems that athletes have used AAS for more than 50 years, with first anecdotal evidence of use of animal testicular extracts even in 1890s (Yesalis 1999). Despite educational and 
preventive measures, steroid use increases (Windsor \& Dumitru 1988). The prevalence of AAS abuse has been reported in several populations. The highest estimates have come from male bodybuilders with even more than 50\% regularly using steroids (Tricker et al. 1989; Lindstrom et al. 1990). Lower rates have been reported among intercollegiate athletes, ranging from $15 \%$ to $20 \%$ (Dezelsky et al. 1985). Rates of steroids use vary greatly across individual sports and are used in higher frequency and higher doses by strength athletes (Sturmi \& Diorio 1998). By contrast, only $1 \%$ of their nonathletic university student counterparts reported steroids use (Dezelsky et al. 1985). Perhaps the most surprising and alarming finding is the rather high rate of steroids abuse among high school students (Mulcahey et al. 2010). The typical rate reported in male students is between $5 \%$ and $6 \%$, but rates as high as $11 \%$ have been reported (Johnson et al 1989). The most recent estimate reported a range of $5 \%$ to $15 \%$ for steroids use among high school boys. In female high school students, steroids abuse rates tend to be lower, but quite worrisome at $1 \%$ to $3 \%$ (Harmer 2010). Wroble and co-workers (2002) indicated that less than one percent $(0.7 \%)$ of youth sports participants reported current or previous usage of anabolic steroids; the rate of usage was higher in males than females. Three percent of athletes had been offered steroids at some time with $22 \%$ of them admitted to using steroids. Of the reported anabolic steroid users, $27 \%$ admitted they used anabolic steroids for athletic performance; $18 \%$ used to improve personal appearance; $18 \%$ used for bodybuilding; and 18\% took due to peer pressure. Twelve percent of all athletes said that they personally know someone who was using or had used steroids.

Although several prohormones are considered as AAS, and are banned by many sports governing bodies, including the International Olympic Committee (IOC), they are semi-legal substances available from many retail outlets, including internet health food stores. The overall prevalence of prohormones use is not known, although several reports indicated that prohormones are among the most popular dietary supplements especially in adolescent athletes (Smurawa \& Congeni 2007). Even though usage has decreased by over $50 \%$ since 1989, steroid use in sport is still a serious problem. Insufficient knowledge and inappropriate attitudes regarding the benefits and risks of using anabolic steroids is also a major concern (Schwingel et al. 2011).

\section{Testosterone production and musculotrophic effects of prosteroids}

The most prevalent reason for athletes initiating AAS or prosteroids use is to promote muscle mass and strength (Yen et al. 1995). From long list of previous studies (for review see Hartgens \& Kuipers 2004) it could be concluded that steroids administration may increase muscle mass. Exogenous testosterone administration (> $125 \mathrm{mg} /$ week), with and without strength training program, may lead to increments of muscle volume and/or muscle fibre size. Yet, lower doses of testosterone (e.g. 25, 50 or $100 \mathrm{mg} /$ week) had no effect on muscle fibre cross-sectional area. It seems that musculotrophic effect of steroids is dose-dependent. Therefore, the effects of prosteroids on muscle size and/or strength is highly influenced by its potential to increase serum testosterone after administration.

Existing data on testosterone-boosting effects of prosteroids are equivocal; it seems that age and basal serum testosterone concentration may influence the response to prosteroids intake (Brown et al. 2000). Several studies reported that serum sex steroid levels in both mature and young men were not significantly affected by prohormone supplementation, with only a minimal amount converted to testosterone and more to estrogen (Vogiatzi et al. 1996; 
Morales et al. 1998; Kroboth et al. 1999; Yamada et al. 2007). No changes in levels of testosterone and estradiol were observed for men after supplementation with $50 \mathrm{mg}$ of DHEA for 3, 6 and 12 months (Von Muhlen et al. 2008). In 19 young men (23 \pm 1 yr old) participating in an 8-week resistance training, ingestion of $150 \mathrm{mg} /$ day of DHEA did not affect serum testosterone and estrogen concentrations (Bowers 1999). On the other hand, ingesting $100 \mathrm{mg}$ of androstenedione t.i.d. for 28 days increases serum-free testosterone concentration by $40 \%$ (Brown et al. 2000; Brown et al. 2001), while $200 \mathrm{mg}$ of androstenediione increases testosterone area under the curve by approximately $15 \%$ during the 90 min post-administration (Earnest et al. 2000). In recent study (Ostojic et al. 2010) intake of DHEA resulted in significant increase of total testosterone in treated subjects after 28-days of supplementation. Accordingly, Wolf et al. (1997) reported 1.3-fold increase in testosterone levels after supplementation with $50 \mathrm{mg}$ oral DHEA for 2 weeks in 25 men. Furthermore, serum estradiol levels were significantly elevated, indicating that a significant portion of the ingested prosteroids underwent aromatization. It seems that both the magnitude of the dose administered and the route of administration affect the extent of change in concentrations of sex hormones (Ziegenfuss et al. 2002). Furthermore, several studies confirm the importance of extraadrenal and extragonadal 3ß-hydroxysterodi dehydrogenase activity in the synthesis of androgens and estrogens after prohormones administration (Nestler et al. 1991; Kroboth et al. 1999).

Not all subjects respond to prohormones in same fashion, suggesting that additional factors (i.e. age, gender, diet, type and intensity of exercise) influence these responses. For example, research demonstrates that prohormone supplementation may acutely increase testosterone levels in women, thus producing a virilizing effect (Bahrke \& Yesalis 2004). Furthermore, exercise could result in increased DHEA and DHEA-S concentrations (Bernton et al. 1995) and these elevated levels in athletes could influence response to supplementation, which requires further investigation. The recent study (Ostojic et al. 2010) reported an increase of total testosterone and estradiol while free testosterone is normal. These data can be consistent with an increase of sex hormone binding globulin (SHBG) by prosteroids administration (Nestler et al. 1991). Total testosterone was increased to keep normal free testosterone or in alternative free testosterone was normal due to an increase activation of 5alpha reductase. Measuring SHBG luteinizing and folicle-stimulating hormone in future studies should prove these hypotheses. However, it is important to point out that simply producing an acute elevation in a particular hormone concentration (i.e. testosterone) does not necessarily result in increases in muscle mass or lean body mass. Prosteroids do not appear to have functional benefits when taken in daily concentrations up to $300 \mathrm{mg}$ per day in young, middle-aged or older men (Wallace et akl. 1999; Ballantyne et al. 2000; Broeder 2003). Although oral DHEA intake enhanced testosterone production for $30 \%$, Ostojic and co-workers (2010) did not found changes in total muscle mass or regional muscularity.

It seems that effect of prosteroids on serum hormones was not mediated by an effect on body composition. Increasing DHEA or other prohormones levels may not provide the optimal anabolic environment desired in spite of elevated total testosterone level, due to several possible mechanisms (i.e. genetic polymorphism of the androgen receptor, potential hormonal interconversions at the paracrine level) (Nestler et al. 1991). Whether the increase of testosterone after intake of prohormones translates into a meaningful change in body composition or rates of muscle protein synthesis is debatable. Studies must be evaluated in terms of the relative potency of various testosterone enhancers with varying effects on 
different tissues according to receptor-binding properties of the compound and its metabolites (Ebeling \& Koivisto 1994). The relative potency of prosteroids seems to be small with inconsiderable advantageous anabolic properties. Several authors hypothesized that an important part of the musculotrophic effect of prosteroids may not be directly mediated through androgen receptors but instead involves interference with catabolic effects produced by glucocorticoid hormones binding to their specific receptors (Bernton et al. 1995; Morales et al. 1998). With an incomplete understanding of how prohormones exert their effects on skeletal muscle, further studies should analyze nitrogen balance indicators as noninvasive approximate index of muscle protein status.

\section{Fat mass alteration and steroid prohormones intake}

In the field of sports and exercise nutrition, prosteroids (DHEA in particular) are often promoted as fat-burning agent that could enhance body physique and estetize appearance (Kroboth et al. 1999). However, clear evidence supporting the use of prosteroids in athletic environment remains less clear. It is well known that age-related decreases in DHEA are associated with increases in obesity and a decline in fat free mass (Morales et al. 1998) yet the potential usefulness of DHEA as a slimming agent is mostly indicated by previous research in animals, particularly lower mammals (Cleary 1991). In the rat plasma concentration of DHEA ranges between 14 and $80 \mathrm{nM}$ while in the plasma of humans DHEA-concentration ranges between 5 and $24 \mathrm{nM}$ and DHEAS-concentration is up to $9 \mu \mathrm{M}$ (Svec \& Porter 1998). The anti-obesity effect of DHEA in animals could be due to several possible mechanisms (Cleary 1991; Ebeling \& Koivisto 1994; Kroboth et al. 1999). However, studies that have investigated the effects of oral prosteroids supplementation on body composition in humans produced equivocal results, particularly in young men.

Nestler et al. (1988) reported that 28-day supplementation with DHEA (1600 mg/day) reduced body fat by $31 \%$ with no change in body mass in five normal men. Serum total testosterone, free testosterone, sex hormone-binding globulin, estradiol, and estrone levels did not change while serum DHEA-S and androstenedione rose 2.0- to 3.5-fold in DHEA group. Morales et al. (1998) founded that $100 \mathrm{mg}$ of DHEA for 6 months induced decrease in body fat mass $(6.1 \pm 2.6 \%)$ in healthy non-obese men. On the other side, several investigators showed that body composition was not affected by prosteroids treatment in young and adult men, both obese and non-obese (Usiskin et al. 1990; Welle et al. 1990; Wallace et al. 1999). Vogiatzi et al. (1996) suggested that DHEA $40 \mathrm{mg}$ administered sublingually twice daily for 8 weeks has no positive effects on body composition in obese young adults. In recent DAWN trial (Von Muhlen et al. 2008) no beneficial effects of $50 \mathrm{mg}$ daily oral DHEA supplementation on body composition were found in 110 healthy mature men. In accordance with above research, the recent study (Ostojic et al. 2010) failed to show any beneficial effects of oral DHEA administration on body mass and body composition in nonobese young athletes. Authors did not found significant reduction in body fat of young soccer players after DHEA supplementation. Other indicators of body fatness (i.e. body mass index, waist-to-hip ratio) remained unchanged during the study in both DHEA and placebo group, indicating that treatment with DHEA does not result in significant changes to justify its use as an antiobesity or slimming agent. As in the case of cognition, negative results in healthy volunteers can be attributed either to a true lack of DHEA effect or to body composition too close to ideal at the study start to detect changes in the small numbers of subjects studied. 
Although most studies found no beneficial effects of prosteroids supplementation on body composition in athletes, several investigators underlined possible beneficial effects of prosteroids supplementation for elderly. Hernandez-Morante et al. (2008) demonstrated for the first time in vitro that DHEA-S stimulates lipolysis in 85 obese patients, preferably in subcutaneous fat in women and in visceral fat in men. A study by Ho et al. (2008) suggested that low DHEA-S is associated with increased waist-to-hip ratio and reduced insulin sensitivity with aging while Hsu et al. (2008) had reported that body composition and insulin sensitivity can change with aging in early lifetime. Benefits of prosteroids supplementation in this regard for early middle-aged people requires more clinical investigation.

Although the body composition changes induced by steroids or prosteroids administration are rather small, after the drug withdrawal the alterations of body composition fade away in slow manner, but may be presented in part for period up to 3 months (Kuipers et al. 1991; Hartgens et al. 2001; Brown et al. 2006). Yet, the final net results of short-term steroids or prosteroids administration on body composition seems to be minute (Hartgens \& Kuipers 2004). This is particularly true for all athletes who are not capable of maintaining the nutritional intake and training workload of the level required for significant body composition changes (Hartgens et al. 1996). It may be important that steroid cessation is followed by a period of hypogonadism, while testicular function gradually returns to normal, over a period of weeks or several months (Hartgens \& Kuipers 2004). Although this has not been specifically studied, reduced circulating androgen during this period may help to accelerate the loss of any anabolic steroid-induced gains. How much of the gain can be sustained by physical training following drug cessation remains to be studied (Yesalis \& Bahrke 2000).

\section{Known and potential health risks of prosteroids administration}

During the past 20 years, researches suggested that potential risk factors associated with prosteroids use were similar to those observed with anabolic steroids (Broeder 2002). The altered hormonal milieu caused by prohormone intake is similar to the hormonal milieu observed in men with gynecomastia, prostate cancer, testicular cancer and pancreatic cancer (Fyssas et al. 1997; Chang et al. 2005). Yet, no documented cases exist of these endocrinerelated diseases caused by prohormone supplementation (Brown et al. 2006). Furthermore, it seems that athletes who regularly use prosteroids experienced several side effects (e.g. fatigue, headache, nasal congestion, acne, increased aggressiveness, increased blood pressure, masculinization in women, gynecomastia and testicular wasting in men) (Broeder et al. 2000). Although prohormones induces small decreases in high-density lipoprotein cholesterol (HDL-C), long-term implications of transient negative changes in blood lipids (e.g. 3-6 mg/dL reductions in HDL-C) have yet to be elucidated as the risk of sustaining a cardiac event (Ziegenfuss et al. 2002).

Regarding unfavourable body composition changes, it has been noted that prohormones could lead to changes in hydration of the fat free mass (via sodium and water retention), which could be interpreted as hyperhydration effect (Casaburi et al. 1996). Whether more prolonged (> 8-12 weeks) prohormones supplementation is safe or useful remains uncertain, but appears unlikely (Ziegenfuss et al. 2002). Although some health risks have been noted, thus far none of the prohormones tested appear to be overly toxic as no elevations in clinically relevant tissue enzymes (e.g. alanine aminotransferase, creatine kinase, aspartate 
aminotransferase, gamma-glutamyltransferase, lactate dehydrogenase) have been observed (Brown et al. 2000; Ziegenfuss et al. 2002). However, due to the lack of efficacy of oral prosteroids supplementation in athletes, its theoretical risks seem to fat outweight any potential benefits on body composition and should be discouraged (Earnest 2001).

\section{Summary}

In the past 20 years, different steroid prohormones or prosteroids have been aggressively marketed in athletic environment as legal nutritional supplements that are expected to convert to active anabolic steroid hormones in the body and enhance exercise performance. Although the mechanism of action of prosteroids is not completely understood it has been promoted that prosteroids increases testosterone production if supplemented in diet and due to its anabolic action may affects nitrogen balance and protein synthesis. Although popular among athletes, studies have demonstrated repeatedly that acute and long-term administration of these oral testosterone precursors does not effectively increase serum testosterone levels and fails to produce any significant changes in lean body mass, muscle strength, or performance improvement compared with placebo. It seems that increasing prohormone levels in athletes may not provide the optimal anabolic environment desired in spite of elevated total testosterone level (at least acutely), due to several possible mechanisms (i.e. genetic polymorphism of the androgen receptor, potential hormonal interconversions at the paracrine level). The relative potency of prosteroids seems to be small with inconsiderable advantageous anabolic properties. Furthermore, recent studies indicates that treatment with prosteroids does not result in significant changes to justify its use as an antiobesity or slimming agent. Not all subjects respond to prohormones in same fashion, suggesting that additional factors (i.e. gender, diet, type and intensity of exercise) influence these responses. Although some health risks have been noted, thus far none of the prohormones tested appear to be overly toxic. Yet, due to the lack of efficacy of oral prosteroids supplementation in athletes, its theoretical risks seem to far outweight any potential benefits on body composition and should be discouraged. Although the understanding of testosterone precursors as performance-enhancing drugs continues to advance, there are likely to be more revelations as scientific investigations continue.

\section{References}

Bahrke, M.S., \& Yesalis, C.E. (2004). Abuse of Anabolic Androgenic Steroids and Related Substances in Sport and Exercise. Current Opinion in Pharmacology. Vol.4, No.6 (December 2004), pp. 614-620, ISSN 1471-4892.

Ballantyne, C.S., Phillips, S.M., MacDonald, J.R., Tarnopolsky, M.A. \& MacDozgall, J.D. (2000). The Acute Effects of Androstenedione Supplementation in Health Young Men. Canadian Journal of Applied Physiology, Vol.25, No.1 (February 2000), pp. 68-78, ISSN 1066-7814.

Baulieu, E.E., Thomas, G., Legrain, S., Lahlou, N., Roger, M., Debuire, B., Faucounau, V., Girard, L., Hervy, M.P., Latour, F., Leaud, M.C., Mokrane, A., Pitti-Ferrandi, H., Trivalle, C., de Lacharrière, O., Nouveau, S., Rakoto-Arison, B., Souberbielle, J.C., Raison, J., Le Bouc, Y., Raynaud, A., Girerd, X., \& Forette, F. (2000). Dehydroepiandrosterone (DHEA), DHEA Sulfate, and Aging: Contribution of the DHEAge Study to a Sociobiomedical Issue. The Proceedings of the National Academy 
of Sciences of the United States of America, Vol.97, No.8, (April 2000), pp. 4279-4284, ISSN 0027-8424.

Bernton, E., Hoover, D., Galloway, R., \& Popp, K. Adaptation to Chronic Stress in Military Trainees: Adrenal Androgens, Testosterone, Glucocorticoids, IGF-1 and Immune Function (1995). Annals of the New York Academy of Sciences, Vol.774, (December 1995), pp. 217-231, ISSN 0077-8923.

Bowers, L.D. Oral Dehydroepiandrosterone Supplementation Can Increase the Testosterone / Epitestosterone Ratio. (1999). Clinical Chemistry, Vol.45, No.2, (February 1999), pp. 295-297, ISSN 0009-9147.

Branium, J. (2008). Bodybuilding Pharmacology. Iron Man Magazine, Vol.72, No.9, (September 2008), pp. 248-250, ISSN 0047-1496.

Breiner, M., Romalo, G. \& Schweikert, H.U. (1986). Inhibition of Androgen Receptor Binding by Natural and Synthetic Steroids in Cultured Human Genital Skin Fibroblasts. Klinische Wochenschrift, Vol.64, No.16, (August 1986), pp. 732-737, ISSN 0023-2173.

Broeder, C.E:, Quindry, J., Brittingham, K., Panton, L., Thompson, J., Appakondu, S., Breuel, K., Byrd, R., Douglas, J., Earnest, C., Mitchell, C., Olson, M., Roy, T. \& Yarlagadda, C. (2000). The Andro project: Physiological and Hormonal Influence of Androstenedione Supplementation in Men 35 to 65 Yeard Old Participating in High-Intensity Resistance Training Program. Archives of Internal Medicine, Vol.160, No.20, (November 2000), pp. 3093-3204, ISSN 0003-9926.

Broeder, C.E. (2003). Oral Andro-Related Prohormone Supplementation: Do the Potential Risks Outweight the Benefits? Canadian Journal of Applied Physiology, Vol.28, No.1, (February 2003), pp. 102-116, ISSN 1066-7814.

Brown, G.A., Vukovich, M.D., Sharp, R.L., Reifenrath, T.A, Parsons, K.A., \& King, D.S. (1999). Effect of Oral DHEA on Serum Testosterone and Adaptations to Resistance Training in Young Men. Journal of Applied Physiology, Vol.87, No.6, (December 1999), pp. 2274-2283, ISSN 8750-7587.

Brown, G.A., Vukovich, M.D., Martini, E.R., et al. (2000). Endocrine Responses to Chronic Androstenedione Intake in 30- to 56-Year-Old Men. Journal of Clinical Endocrinology and Metabolism, Vol.85, No.11, (November 2000), pp. 4074-4080. ISSN 0021-972X.

Brown, G.A., Vukovich, M.D., Martini, E.R., Kohut, M,L, Franke, W.D., Jackson, D.A. \& King DS. (2001). Effects of Androstenedione-Herbal Supplementation on Serum Sex Hormone Concentration in 30- to 59-Year-Old Men. International Journal for Vitamin and Nutrition Research, Vol.71, No.5, (September 2001), pp. 293-301. ISSN 0373-0883.

Brown, W.J., Basil, M.D., \& Bocarnea, M.C. (2003). The Influence of Famous Athletes on Health Beliefs and Practices: Mark McGwire, Child Abuse Prevention, and Androstenedione. Journal of Health Communications, Vol.8, No.1, (January-February 2003), pp. 41-57, ISSN 1081-0730.

Brown, G.A., Vukovich, M. \& King, D.S. (2006). Testosterone Prohormone Supplements. Medicine and Science in Sports and Exercise, Vol.38, No.8, (August 2006), pp. 14511461. ISSN 0195-9131.

Casaburi, R, Storer, T. \& Bhasin, S. (1996). Androgen Effects on Body Composition and Muscle Performance. In: Pharmacology, Biology, and Clinical Applications of Androgens, S. Bhasin, H. Gabelnick, J. Spieler, R. Swerdloff, C. Wang, \& C. Kelly, (Eds.), pp. 487-491, Wiley-Liss, Inc., ISBN 978-047-1133-20-9, New York. 
Chang, S.S., Ivey, B., Smith, A., Roth, B.J. \& Cookson, M.S. (2005). Performance-Enhancing Supplement Use in Patients with Testicular Cancer. Urology, Vol.66, No2, (August 2006), pp. 242-245, ISSN 0834-6747.

Cleary, M.P. (1991). The Antiobesity Effect of Dehydroepiandrosterone in Rats. Procceedings of the Society of Experimental Biology and Medicine,Vo.196, No.1, (January 1991), pp. 816, ISSN 0037-9727.

Creutzberg, E.C., \& Schols, A.M. (1998). Anabolic Steroids. Current Oppinion in Clinical Nutrition and Metabiolic Care, Vol.2, No.3, (May 1998), pp. 243-253, ISSN 1363-1950.

Dezelsky, T.L., Toohey, J.V. \& Shaw, R.S. (1985). Non-Medical Drug Use Behaviour at Five United States Universities: A 15-year Study. Bulletin on Narcotics, Vol.37, N.2-3, (April-September 1985), pp. 49-53, ISSN 0007-523X.

Earnest, C.P. (2001). Dietary androgen 'supplements': separating substance from hype. Physisian and Sportsmedicine. Vol.29, No.5, (May 2001), pp. 63-79, ISSN 0091-3847.

Earnest, C.P., Olson, M.A., Broeder, C.E., Breuel, K.F. \& Beckham, S.G. (2000). In Vivo 4Androstene-3, 17-Dione and 4-Androstene-3 Beta, 16 Beta-Diol Supplementation in Young Men. European Journal of Applied Physiology, Vol.81, No.3, (February 2000), pp. 229-232. ISSN 1439-6319.

Ebeling, P., \& Koivisto, V.A. (1994). Physiological Importance of Dehydroepiandrosterone. Lancet, Vol.343, No.8911, (June 1994), pp. 1479-1481, ISSN 0140-6736.

Evans, N.A. (2004). Current concepts in anabolic-androgenic steroids. American Journal of Sports Medicine, Vol.32, No.2, (March 2004), pp. 534-542, ISSN 0363-5465.

Foster, Z.J, \& Housner, J.A. (2004). Anabolic-androgenic steroids and testosterone precursors: ergogenic aids and sport. Curr Sports Medicine Reports. Vol.3, No.4, (August 2004), pp. 234-241, ISSN 1537-890X.

Fyssas, I, Syrigos, K.N., Konstandoulakis, M.M., Papadopoulos, S., Milingos, N., Anapliotou, M., Waxman, J. \& Golematis, B.C. (1997). Sex Hormone levels in the Serum of Patients with Pancreatic Adenocarcinoma. Hormone and Metabolic Research.Vol.29, No.3, (March 1997), pp. 115-118, ISSN 0018-5043.

Griffin, J.E., \& Ojeda, S.R. (2004). Textbook of Endocrine Physiology (5th ed), Oxford University Press, ISBN 978-019-5165-66-1, New York, USA.

Harmer, P.A. (2010). Anabolic-Androgenic Seroid Use Among Young Male and Female Athletes: Is the Game to Blame? British Journal of Sports Medicine, Vol.44, No.1, (January 2010), pp. 26-31, ISSN 0306-3674.

Hartgens, F., Kuipers, H., Wijnen, J.A. \& Keizer, H.A. (1996). Body Composition, Cardiovascular Risk Factor and Liver Function in Long Term Androgenic-Anabolic Steroids Using Bodybuilders Three Months After Drug Withdrawal. International Journal of Sports Medicine, Vol.17, No.6, (August 1996), pp. 429-433, ISSN 0172-4622.

Hartgens, F., Van Marken Lichtenbelt, W.D., Ebbing, S., Vollaard, N., Rietjens, G. \& Kuipers, H. (2001). Body Composition and Anthropometry in Bodybuilders: regional Changes Due to Nandrolone Decanoate Administration. Intrenational Journal of Sports Medicine, Vol.22, No.3, (April 2001), pp. 235-241, ISSN 0172-4622

Hartgens, F.\& Kuipers, H. (2004). Effects of Androgenic-Anabolic Steroids in Athletes. Sports Medicine, Vol.34, No.8, (August 2004), pp. 513-554. ISSN 0112-1642.

Hernández-Morante, J.J., Pérez-de-Heredia, F., Luján, J.A., Zamora, S., \& Garaulet, M. (2008). Role of DHEA-S on Body Fat Distribution: Gender- and Depot-Specific 
Stimulation of Adipose Tissue Lipolysis. Steroids, Vol.73, No.2, (February 2008), pp. 209-215, ISSN 0039-128X.

Ho, C.T., Su, C.L., Chen, M.T., Liou, Y.F., Lee, S.D., Chien, K.Y., \& Kuo, C.H. Aging Effects on Glycemic Control and Inflammation for Politicians in Taiwan. Chininese Journal of Physiology, Vol.51, No.6, (December 2008), pp. 402-407, ISSN 0304-4920.

Hsu, T.H., Liu, Y.F., Lee, S.D., Chen, S.M., Lee, J.P., Fang, C.L., Liu, T.C., \& Kuo, C.H. (2008). Suppression of Age-Dependent Increase in Insulinemia in Early Middle-Aged Females with Exercise Habit. Chinese Journal of Physioligy, Vol.51, No.5, (October 2008), pp. 263-268, ISSN 0304-4920.

International Olympic Committee. (1999). Statistics 1997 of the IOC Accredited Laboratories, International Olympic Committee, Lausanne, Switzerland.

Johnson, M.D., Jay, M.S., Shoup, B. \& Rickert, V.I. (1989). Anabolic Steroid Use by Male Adolescents. Pediatrics, Vol.83, No.6, (June 1989), pp. 921-924, ISSN 0031-4005.

Kanayama, G., Gruber, A.J., Pope Jr, H.G., Borowiecki, J.J. \& Hudson, J.I. (2001). Over-theCounter Drug Use in Gymnasiums: An Underrecognized Substance Abuse Problem? Psychotherapy and Psychosomatics, Vol.70, No.3, (May-June 2001), pp. 137140, ISSN 0033-3190.

Kerr, J.M. \& Congeni, J.A. (2007). Anabolic-Androgenic Steroids: Use and Abuse in Pediatric Patients. Pediatric Clinics of North America, Vol.54, No.4, (August 2007), pp. 771-785, ISSN 0031-3955.

King, D.S., Sharp, R.L., Vukovich, M.D., Brown, G.A., Reifenrath, T.A., Uhl, N.L. \& Parsons, K.A. (1999). Effect of Oral Androstenedione on Serum Testosterone and Adaptations to Resistance Training in Youung Men; A Randomised Controlled Trial. JAMA, Vol.218, No.21, (June 1999), pp. 2020-2028. ISSN 0098-7484.

Kroboth, P.D., Salek, F.S., Pittenger, A.L., Fabian, T.J., \& Frye R.F. (1999). DHEA and DHEAS: a Review. Journal of Clinical Pharmacology, Vol.39, No.4, (April 1999), pp. 327-348, ISSN 0091-2700.

Kuipers, H., Wijnen, J.A, Hartgens, F. \& Willems, S.M. (1991). Influence of Anabolic Steroids on Body Composition, Blood Pressure, Lipid Profile and Liver Function in Bodybuilders. International Journal of Sports Medicine, Vol.12, No.4, (August ), pp. 413-418, ISSN 0172-4622.

Leder, B.Z., Longcope, C., Catlin, D.H., Ahrens, B., Schonefeld, D.A. \& Finkelstein, J.S. (2000). Oral Androstenedione Administration and Serum Testosterone Concentration in Young Men. JAMA, Vol.284, No.6, (February 2000), pp. 779-782. ISSN 0098-7484.

Lindstrom, M., Nilsson, A.L., Katzman, P.L., Janzon, L., \& Dymling, J.F. (1990). Use of Anabolic-Androgenic Steroids Among Body Builders - Frequency and Attitudes. Journal of Internal Medicine, Vol.227, No.6, (June 1990), pp. 407-411, ISSN 0954-6820.

Mohan, P.F. \& Cleary, M.P. (1988). Effects of Short-Term DHEA Administration on Liver Metabolism of Lean and Obese Rats. American Journal of Physiology, Vol.255, No1. (July 1988), pp. E1-E8, ISSN 0002-9513.

Morales, A.J., Haubrich, R.H., Hwang, J.Y., Asakura, H., \& Yen, S.S. (1998). The Effect of Six Months Treatment with a $100 \mathrm{mg}$ Daily Dose of Dehydroepiandrosterone (DHEA) on Circulating Sex Steroids, Body Composition and Muscle Strength in AgeAdvanced Men and Women. Clinical Endocrinology, Vol.49, No.4, (October 1998), pp. 421-432, ISSN 0300-0664. 
Mulcahey, M.K., Schiller, J.R. \& Hulstyn, M.J. (2010). Anabolic Steroid Use in Adolescents: Identification of those at Risk and Strategies for Prevention. The Physician and Sportsmedicinei, Vol.38, No.3, (October 2010), pp. 105-113, ISSN 0091-3847.

Nestler, J.E., Barlascini, C.O., Clore, J.N., \& Blackard, W.G. (1988). Dehydroepiandrosterone Reduces Serum Low Density Lipoprotein Levels and Body Fat but Does Not Alter Insulin Sensitivity in Normal Men. Journal of Clinical Endocrinology and Metabolism, Vol.66, No.1, (January 1988), pp. 57-61, ISSN 0021-972X.

Nestler, J.E., Clore, J.N., \& Blackard, W.G. (1991). Metabolism and Actions of Dehydroepiandrosterone in Humans. Journal of Steroid Biochemistry and Molecular Biology, Vol.40, No.4-6, (June 1991), pp. 599-605, ISSN 0960-0760.

Ostojic, S.M., Calleja-Gonzalez, J. (2009). Ergogenic supplements for endurance performance: science vs. hype. Proceedings of the Exercise Training Physiology Symposium, Cordoba, Argentina, June 2009, Available from http://www.sobreentrenamiento.com/CurCE/Simposios/Informacion.asp?sim=P S2

Ostojic, S.M, Calleja-Gonzalez, J. \& Jourkesh, M. (2010). Effects of short-term dehydroepiandrosterone supplementation on body composition in young athletes. Chinese Journal of Physiology, Vol.53, No.1, (February 2010), pp. 19-25, ISSN 03044920.

Saartok, T., Dahlberg, E. \& Gustafsson, J.A. (1984). Relative Binding Affinity of AnabolicAndrogenic Steroids: Comparison of the Binding to the Androgen Receptors in Skeletal Muscle and in Prostate, as well as to Sex Hormone-Binding Globuline. Endocrinology, Vol. 114, No.6, (June 1984), pp. 2100-2106, ISSN 0013-7227.

Schwingel, P.A., Cotrim, H.P., Salles, B.R., Almeida, C.E., dos Santos, C.R. Jr, Nachef, B., Andrade, A.R., \& Zoppi, C.C. (2011). Anabolic-androgenic steroids: a possible new risk factor of toxicantassociated fatty liver disease. Liver International, Vol.31, No.3, (March 2011), pp. 348-353, ISSN 1478-3223.

Smurawa, T.M. \& Congeni, J.A. (2007). Testosterone Precursors: Use and Abuse in Pediatric Athletes. Pediatric Clinics of North America, Vol.54, No.4, (August 2007), pp. 787-796, ISSN 0031-3955.

Sturmi, J.E. \& Diorio, D.J. (1998). Anabolic Agents. Clinics in Sports Medicine, Vol.17, No.2, (April 1998), pp. 261-282, ISSN 0278-5919

Svec, F., \& Porter, J.R. (1998). The Actions of Exogenous Dehydroepiandrosterone in Experimenatl Animals and Humans. Proceedings of the Society for Experimental Biology and Medicine, Vol.218, No.3, (July ), pp. 174-191, ISSN 0037-9727.

Tagliaferro, A.R., Davies, J.R., Truchon, S. \& Van Hamont, N. (1986). Effects of Dehydroepiandrosterone Acetate on Metabolism, Body Weight, and Composition of male and Female Rats. Journal of Nutrition, Vo.116, No.10, (October 1986), pp. 1977-1983, ISSN 0022-3166.

Tricker, R., O'Neill, M.R. \& Cook, D. (1989). The Incidence of Anabolic Steroid Use Among Competitive Bodybuilders. Journal of Drug Education, Vol.19, No.4, (April 1989), pp. 313-325, ISSN 0047-2379

Usiskin, K.S., Butterworth, S., Clore, J.N., Arad, Y., Ginsberg, H.N., Blackard, W.G., \& Nestler, J.E. (1990). Lack of Effect of Dehydroepiandrosterone in Obese Men. International Journal of Obesity, Vol.14, No.5, (May 1990), pp. 457-463, ISSN 03070565 . 
Vogiatzi, M.G., Boeck, M.A., Vlachopapadopoulou, E., el-Rashid, R., \& New, M.I. (1996). Dehydroepiandrosterone in Morbidly Obese Adolescents: Effects on Weight, Body Composition, Lipids, and Insulin Resistance. Metabolism, Vol.45, No.8, (August 1996), pp. 1011-1015, ISSN 0026-0495.

Von Muhlen, D., Laughlin, G.A., Kritz-Silverstain, D., Bergstrom, J., and Bettencourt, R. (2008). Effect of Dehydroepiandrosterone Supplementation on Bone Mineral Density, Bone Markers, and Body Composition in Older Adults: The DAWN Trial. Osteoporosis International, Vol.19, No.5, (May 2008), pp. 699-707, ISSN 0937-941X

Wallace, M.B., Lim, J., Cutler, A. \& Bucci, L. (1999). Effects of Dehydroepiandrosterone vs. Androstenedione Supplementation in Men. Medicine and Science in Sports and Exercise, Vol.31, No.12, (Decemebr 1999), pp. 1788-1792, ISSN 0195-9131.

Welle, S., Jozefowicz, R., \& Statt, M. (1990). Failure of Dehydroepiandrosterone to Influence Energy and Protein Metabolism in Humans. Journal of Clinical Endocrinology and Metabolism, Vol.71, No.5, (November 1990), pp. 1259-1264, ISSN 0021-972X.

Wilson, J.D. (1988). Androgen Abuse by Athletes. Endocrinology Review, Vol.9, No.2, (May 1988), pp. 181-199, ISSN 0163-769X.

Windsor, R. \& Dumitru, D. (1989). Prevalence of anabolic steroid use by male and female adolescents. Medicine and Science in Sports and Exercise, Vol.21, No.5, (October 1989), pp. 494-497, ISSN 0195-9131.

Wolf, O.T., Neumann, O., Hellhammer, D.H., Geiben, A.C., Strasburger, C.J., Dressendörfer, R.A., Pirke, K.M., \& Kirschbaum, C. (1997). Effects of a Two-Week Physiological Dehydroepiandrosterone Substitution on Cognitive Performance and Well-Being in Healthy Elderly Women and Men. Journal of Clinical Endocrinology and Metabolism, Vol.82, No.7, (July 1997), pp. 2363-2367, ISSN 0021-972X.

Wroble, R.R, Gray, M. \& Rodrigo, J. (2002). Anabolic Steroids and Pre-adolescent Athletes: Prevalence, Knowledge, and Attitudes. Sport Journal, Vol.5, No.3, (March 2002), pp. 1-8, ISSN 1543-9518.

Yamada, Y., Sekihara, H., Omura, M., Yanase, T., Takayanagi, R., Mune, T., Yasuda, K., Ishizuka, T., Ueshiba, H., Miyachi, Y., Iwasaki, T., Nakajima, A., \& Nawata, H. (2007). Changes in Serum Sex Hormone Profiles after Short-Term Low-Dose Administration of Dehydroepiandrosterone (DHEA) to Young And Elderly Persons. Endocrine Journal, Vol.54, No.1, (February 2007), pp. 153-162, ISSN 09188959.

Yen, S.S., Morales, A.J., \& Khorram, O. (1995). Replacement of DHEA in aging men and women. Potential remedial effects. Annals of the New York Academy of Sciences, Vol.774, (December 1995), pp. 128-142, ISSN 0077-8923.

Yesalis, C.E., Streit, A.L., Vicary, J.R., Friedl, K.E., Brannon, D. \& Buckley, W. (1989). Anabolic Steroid Use: Indications of Habituation Among Adolescents. Journal of Drug Education, Vol.19, No.2, (April 1989), pp. 103-116, ISSN 0047-2379.

Yesalis, C.E., Bahrke M,S. (1995). Anabolic-Androgenic Steroids: Current Issues. Sports Medicine, Vol.19, No. 5, (May 1995), pp. 326-340, ISSN 0112-1642

Yesalis, C.E. (1999). Medical, Legal and Societal Implications of Androstenedione Use. JAMA, Vol.281, No.21 (June 1999), pp. 2043-2044, ISSN 0098-7484.

Yesalis, C.E. \& Bahrke, M.S. (2000). Doping among adolescent athletes. Baillière's best practice $\mathcal{E}$ research. Clinical endocrinology \& metabolism, Vol.14, No.1, (March 2000), pp. 25-35, ISSN 0950-351X. 
Ziegenfuss, T.N., Berardi, J.M., Lowery, L.M \& Antonio, J. (2002). Effects of Prohormone Supplementation in Humans: A Review. Canadian Journal of Applied Physiology, Vol.27, No.6, (December 2002), pp. 628-645, ISSN 1066-7814. 


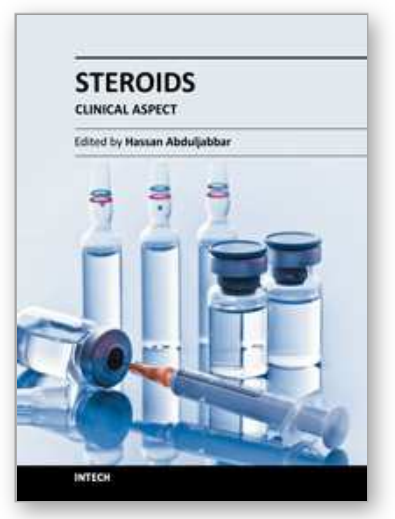

\author{
Steroids - Clinical Aspect \\ Edited by Prof. Hassan Abduljabbar
}

ISBN 978-953-307-705-5

Hard cover, 166 pages

Publisher InTech

Published online 19, October, 2011

Published in print edition October, 2011

Steroids: The basic science and clinical aspects covers the modern understanding and clinical use of steroids. The history of steroids is richly immersed and runs long and deep. The modern history of steroids started in the early 20th century, but its use has been traced back to ancient Greece. We start by describing the basic science of steroids. We then describe different clinical situations where steroids play an important role. We hope that this book will contribute further to the literature available about steroids and enables the reader to further understand this interesting and rapidly evolving science.

\title{
How to reference
}

In order to correctly reference this scholarly work, feel free to copy and paste the following:

Sergej M. Ostojic, Julio Calleja-Gonzalez and Marko Stojanovic (2011). Steroid Prohormones: Effects on Body Composition in Athletes, Steroids - Clinical Aspect, Prof. Hassan Abduljabbar (Ed.), ISBN: 978-953-307-705-5, InTech, Available from: http://www.intechopen.com/books/steroids-clinical-aspect/steroid-prohormones-effectson-body-composition-in-athletes

\section{INTECH}

open science / open minds

\section{InTech Europe}

University Campus STeP Ri

Slavka Krautzeka 83/A

51000 Rijeka, Croatia

Phone: +385 (51) 770447

Fax: +385 (51) 686166

www.intechopen.com

\section{InTech China}

Unit 405, Office Block, Hotel Equatorial Shanghai

No.65, Yan An Road (West), Shanghai, 200040, China

中国上海市延安西路65号上海国际贵都大饭店办公楼405单元

Phone: +86-21-62489820

Fax: +86-21-62489821 
(C) 2011 The Author(s). Licensee IntechOpen. This is an open access article distributed under the terms of the Creative Commons Attribution 3.0 License, which permits unrestricted use, distribution, and reproduction in any medium, provided the original work is properly cited. 